\title{
The Teaching of Altiero Spinelli
}

\section{Paolo Ponzano}

In a historical moment in which the project of European integration risks its disintegration or a substantial deadlock, and in which the disaffection of European citizens towards this project has reached the highest peak in recent years, recalling the teachings of one of the fathers founders of the European project constitutes not only a dutiful homage to the genius of his thought, but also and above all an invitation to his followers to resume the political action undertaken by Altiero Spinelli to achieve the goal of a federal Europe. In fact, if the goal of a federal Europe remained a constant of Spinelli's thought, from his writing with Ernesto Rossi and Eugenio Colorni of the Ventotene Manifesto in 1941 up to the vote on his draft Treaty for the European Union of 1984 and his disappearance two years later, the action strategy pursued by Spinelli to reach the end of a federal Europe varied at least five times over the years. The initial action strategy rested on the hypothesis that the democratic rebirth of the European states after the war would coincide with the elimination of the nation-state and the contemporary advent of a European federal state. When this hypothesis could not be realized, Spinelli became "adviser of the princes", and tried to convince the moderate European leaders - starting from Alcide De Gasperi - to exploit the support of the United States and the fear of Stalinist communism to create a "political European Community". When this perspective faded, due to the rejection of the European Defense Community (EDC) by the French Parliament, Spinelli tried to mobilize the widespread proEuropean sentiment into popular action - the Congress of the European people - directed against the legitimacy of the nation states. The failure of this strategy led Spinelli to rethink the federalist action and his initial criticism of the European Economic Community, which was being built based on the functionalist method. In 1970, Spinelli, appointed European Commissioner by the Italian government, tried to convince the European Commission to take on the role of political leader of the European project. When this hypothesis was not realized, Spinelli turned to the European Parliament to take on a constituent role in the integration process. His Draft Treaty establishing the European Union, voted by a large majority in the European Parliament in 1984, marks the beginning of the process of constitutionalisation of the European Union and, despite being replaced by the less ambitious "Single Act" in 1986, will see the great majority of its innovatory provisions included in the subsequent European Treaties. Therefore Spinelli, far from slavishly repeating the slogans of the Ventotene Manifesto, has always adapted his action strategy to achieve the goal of a federal Europe considering the historical changes taking place. The political action for a federal Europe could not be the same when a cold war was in progress between two opposing blocs, and in the next period of peaceful coexistence. In the same way, today's reality of a multipolar world that sees the affirmation of new regional powers and the phenomenon of mass migrations cannot be tackled by merely repeating the slogans of the federalist movement. When Spinelli got ready in 1978 to undertake his constitutional action in the European Parliament, he addressed himself directly to the federalist organizations of which he had been the main promoter with the following words: "I know that the (federalist) movement is tired, full of scars, more able to consecrate themselves abstractly to an ideal 
action than to conduct political struggles, more inclined to fall back on his pride of precursor than to open up to new forces, which will not necessarily be responsive to our ideas. This is the price of a long desert crossing. But today is the great opportunity to finally lead the battle you have dreamed for so many years. Be ready to seize it!'Words of great relevance. Therefore, Altiero Spinelli's teaching still retains its full validity today. As Lucio Levi rightly points out in his brilliant post-faction to the recently re-edited Ventotene Manifesto, Altiero Spinelli belongs to the category of "historical/universal" men, according to the definition given by Hegel ("Historical/universal individuals - wrote Hegel - are those who first said what men want"). As Lucio Levi wrote, "Spinelli belonged to this category of men".

Like all historical men, he expressed the deepest tendencies of our age and identified himself so much with them that his individual end coincided with the universal end of the whole of the peoples of Europe. The purpose that he pursued was not something arbitrary, but corresponded to the needs of a phase of history and belonged to the real possibilities of our time". In fact, the political action of Altiero Spinelli did not limit itself to proposing yet another project of European unity, as proposed by several precursors of the European project from the thirteenth century to the present day (from Pierre du Bois and the king of Bohemia up to Aristide Briand), but he worked to implement it during his own generation. As Spinelli wrote in a commentary on the Ventotene Manifesto, the first fundamental political idea "was that the (European) federation was not presented as a beautiful ideal, to pay homage and then deal with something else, but as a goal for the realization of which we needed to act now, in our current generation. It was not an invitation to dream, but an invitation to work". In fact,Altiero Spinellihas pursued throughout the whole of his political struggle for the European federation Mazzini's binomial "thought and action": it is not enough to conceive yet another project for the European federal unity, if one does not act concretely for its realization. When Spinelli undertook in July 1980 the initiative of the "Crocodile Club" (from the name of the restaurant where he gathered the first European parliamentarians wishing to propose a constitutional reform of the European Community), there were only eight MEPs willing to follow him. At the time of the vote on his Draft Treaty, the favorable votes became 237 (with 31 against and 43 abstentions). This result was only possible thanks to the tireless activism of Spinelli, who gradually obtained the adhesion in Italy by Enrico Berlinguer, Bettino Craxi, Giorgio Ruffolo, Gaetano Arfé, Mauro Ferri and Mario Zagari; in Germany by Willy Brandt, Katherina Focke and Erwin Lange; in Belgium by Leo Tindemans, etc. After the EP vote, Spinelli even went to the Élysée to convince François Mitterrand to support the Treaty, and obtained the French President's declaration in Strasbourg according to which France declares itself ready to examine a new draft Treaty whose spirit suits them. Therefore, Spinelli's teaching remains valid today. It is not enough to elaborate a good draft of a new treaty (be it the proposal of "Fundamental Law" drawn up by the English federalist Andrew Duff and endorsed by the Spinelli Group in the EP, or the "Frankfurt Protocol" elaborated also by A. Duff as a Treaty for the Eurozone). It would be necessary for the European Parliament to cease quibbling and vote on one of the two projects, in order to use its new powers available under the Lisbon Treaty, and start with a proposal of its own the procedure for revising the Treaties. And it would also be necessary that a new Spinelli would be able to use the art of Socrate's maieutic and persuade today's European political leaders to support him.

Only in this way would the followers of Altiero Spinelli demonstrate, beyond the formal ceremonies in which they pay him homage, that they consider his teaching still valid and that they put it into practice. 